\title{
Direct Radioimmunoassay of Nuclear 3,5,3' Triiodothyronine in Rat Anterior Pituitary
}

\author{
P. R. Larsen, S. Z. Bavli, M. Castonguay, and R. Jove, Howard Hughes Medical \\ Institute Laboratory and Thyroid Unit, Department of Medicine, Peter Bent \\ Brigham Hospital, A Division of the Affiliated Hospitals Center, Inc., and \\ Harvard Medical School, Boston, Massachusetts 02115
}

A B S T R A C T Previous tracer studies have suggested that $5^{\prime}$-monodeiodination of L-thyroxine $\left(\mathrm{T}_{4}\right)$ in anterior pituitary may contribute a substantial portion of specifically bound nuclear 3,5,3' L-triiodothyronine $\left(\mathrm{T}_{3}\right)$ in this tissue in rats. To evaluate this possibility, a radioimmunoassay for nuclear $T_{3}$ in individual anterior pituitaries was developed. Animals received [ $\left.{ }^{125} \mathrm{I}\right]$ $\mathrm{T}_{3} 60 \mathrm{~min}$ before removal of the anterior pituitary and isolation of the nuclei by differential centrifugation. This allowed calculation of the nuclear:serum $T_{3}$ ratio and comparison of expected with measured $\mathrm{T}_{3} . \mathrm{T}_{3}$ was extracted in ethanol, dried, and reconstituted in assay buffer. In untreated hypothyroid rats, anterior pituitary nuclear $\mathrm{T}_{3}$ was $0.18 \pm 0.06 \mathrm{pg} / \mu \mathrm{g}$ DNA which was $0.13 \mathrm{pg} / \mu \mathrm{g}$ DNA greater than expected from the serum $\mathrm{T}_{3}$ concentration and the pituitary nuclear:serum $\left.{ }^{[25} \mathrm{I}\right] \mathrm{T}_{3}$ ratio. In 10 hypothyroid rats given a single bolus of $400 \mathrm{ng} \mathrm{T}_{3} / 100 \mathrm{~g}$ body wt., the nuclear $\mathrm{T}_{3}$ by radioimmunoassay was $1.0 \pm 0.06 \mathrm{pg} / \mu \mathrm{g} \mathrm{DNA}$, whereas that expected from the $T_{3}$ specific activity calculations was $0.85 \mathrm{pg} / \mu \mathrm{g}$ DNA $(\mathrm{P}<0.025)$. Serum $\mathrm{T}_{4}$ concentrations in these rats were $<0.25 \mu \mathrm{g} / \mathrm{dl}$ but the nuclear $\mathrm{T}_{3}$ derived from as little as $0.2 \mu \mathrm{g} / \mathrm{dl} \mathrm{T}_{4}$ could explain a large portion of these small discrepancies between observed and measured nuclear $\mathrm{T}_{3}$. In 29 normal rats, anterior pituitary nuclear $T_{3}$ was $0.63 \pm 0.04 \mathrm{pg} / \mu \mathrm{g}$ DNA, whereas that expected from the serum $T_{3}$ concentration $(55 \pm 2 \mathrm{ng} / \mathrm{dl}$ ) was $0.23 \pm 0.02 \mathrm{pg} / \mu \mathrm{g}$ DNA $(\mathrm{P}<0.001)$. Total pituitary $\mathrm{T}_{3}$ based on this measurement was $92 \pm 6 \mathrm{pg}$. Because the maximal nuclear binding capacity for $\mathrm{T}_{3}$ in rat anterior pituitary is 0.77 $\mathrm{pg} / \mu \mathrm{g}$ DNA, these results suggest there is $82 \%$ occupancy of these nuclear receptors. The requirement for normal serum concentrations of both $T_{4}$ and $T_{3}$ to achieve normal nuclear $T_{3}$ saturation in anterior

Dr. Bavli was the recipient of a National Research Service Award HL-05114.

Received for publication 20 August 1979 and in revised form 29 October 1979. pituitary is in marked contrast to the situation in liver, kidney, and heart muscle which appear to require only a normal serum $T_{3}$. As a consequence, the anterior pituitary can monitor both serum $\mathrm{T}_{4}$ and $\mathrm{T}_{3}$ and respond appropriately to changes in their concentrations.

\section{INTRODUCTION}

Recent in vivo and in vitro studies in hypothyroid rats have demonstrated that there is rapid intrapituitary monodeiodination of L-thyroxine $\left(\mathrm{T}_{4}\right)^{1}$ to $3,5,3^{\prime} \mathrm{L}$ triiodothyronine $\left(\mathrm{T}_{3}\right)$ and that this conversion is required for the rapid inhibition of thyroid-stimulating hormone $(\mathrm{TSH})$ release found after infusion of physiological quantities of $T_{4}(1-5)$. Conversion of $T_{4}$ to $T_{3}$ also occurs in pituitaries of euthyroid rats $(4-7)$. Tracer studies in these animals have suggested that the contribution of intrapituitary $\mathrm{T}_{4} 5^{\prime}$-monodeiodination to pituitary nuclear $T_{3}$ is equal to the quantity of nuclear $\mathrm{T}_{3}$ derived directly from the serum (6). As a result, we estimated that the anterior pituitary nuclear $\mathrm{T}_{3}$ receptors were $\sim 80 \%$ saturated due to this additional source of $\mathrm{T}_{3}$ whereas nuclear receptors in liver and kidney, where this reaction contributes less to nuclear $T_{3}$, were only $50 \%$ saturated. If this is the case, it has important physiological implications regarding the feedback regulation of thyrotropin (TSH) secretion by thyroid hormones. It also raises the possibility that individual tissues might have the capacity to regulate the local intracellular $T_{3}$ concentration instead of depending entirely on the circulation for this hormone.

Comparison of the radioimmunoassayable nuclear $\mathrm{T}_{3}$ in single anterior pituitaries with that expected from the serum $T_{3}$ in the same rats has not been reported. If our previous studies using tracer $T_{3}$ and $T_{4}$ are

${ }^{1}$ Abbreviations used in this paper: BSA, bovine serum albumin; GAB, glycine acetate buffer; RIA, radioimmunoassay; $t_{m}$, equilibrium time; TSH, thyroid-stimulating hormone; $\mathrm{T}_{4}$, L-thyroxine; $\mathrm{T}_{3}, 3,5,3^{\prime}$ L-triiodothyronine. 
valid, substantially greater quantities of radioimmunoassayable nuclear $T_{3}$ should be present in the anterior pituitary than can be accounted for by the concentration of serum $T_{3}$ and the nuclear:serum $T_{3}$ ratio. Our earlier attempts at these analyses were hampered by the presence of " $T_{3}$-like" material that eluted from the resin used to extract $T_{3}$ from the pituitary nuclei (8). This background material was present in sufficiently high quantities that the estimated pituitary nuclear $T_{3}$ concentrations in normal rats were highly variable. Using the present methodology, this problem has been eliminated and reproducible results have been obtained.

\section{METHODS}

Injections and isolation of anterior pituitary nuclei. Sprague-Dawley rats were obtained from Zivic-Miller Laboratories, Allison Park, Pa. Some rats were thyroidectomized by the supplier and parathyroid glands reimplanted in the neck. They received Purina Rat Chow (Ralston Purina Co., St. Louis, Mo.) and tap water with no added calcium. Thyroidectomized animals were kept for a period of at least 2 mon until their weight gain had plateaued before being used in these experiments.

Pituitary nuclear:serum [ $\left.{ }^{125} \mathrm{I}\right] \mathrm{T}_{3}$ ratios and pituitary nuclear $\mathrm{T}_{3}$ radioimmunoassay (RIA) measurements were obtained for each pituitary. Intravenous injections of ${ }^{125} \mathrm{I} \mathrm{T}_{3} \pm$ unlabeled $\mathrm{T}_{3}$ were given via the jugular vein under light ether anesthesia $60 \mathrm{~min}$ before killing the rats. About $1 \mathrm{ml}$ whole blood was removed for base-line $\mathrm{T}_{3}, \mathrm{~T}_{4}$ and TSH measurements before tracer $\mathrm{T}_{3}$ injection. For tracer studies, $10-20 \mu \mathrm{Ci}$ of ${ }^{[25} \mathrm{I}^{1} \mathrm{~T}_{3}(3,300 \mu \mathrm{Ci} / \mu \mathrm{g})$ were given per rat. This was dissolved in phosphate-buffered saline (pH 7.4) with $10 \%$ normal rat serum as carrier protein. Rats received $0.2 \mathrm{ml}$ of this solution $/ 100 \mathrm{~g}$ body wt. Animals were killed by exsanguination through the aorta under ether anesthesia and anterior pituitaries removed and nuclei isolated by the method of Samuels and Tsai, (9) slightly modified. The procedure consisted of an initial homogenization of pituitary tissue in 2.5 $\mathrm{ml}$ cold $0.25 \mathrm{M}$ sucrose, $1.1 \mathrm{m.M} \mathrm{MgCl}_{2}, 0.02 \mathrm{M}$ Tris, $\mathrm{pH} 7.85$. The pituitaries were centrifuged at $1,000 \mathrm{~g}$ for $10 \mathrm{~min}$ and the nuclear pellet washed twice with $2.5 \mathrm{ml}$ cold $0.25 \mathrm{M}$ sucrose, $1.1 \mathrm{mM} \mathrm{.MgCl}, 0.02 \mathrm{M}$ Tris, $\mathrm{pH} 7.85$ containing $0.5 \%$ Triton X-100 (Rohm and Haas Co., Philadelphia, Pa.) After this, the pellet was washed two times with $2.5 \mathrm{ml} 0.15 \mathrm{M} \mathrm{NaCl}$ at $4^{\circ} \mathrm{C}$ to remove residual Triton. Only isolated nuclei were seen by phase-contrast microscopy of nuclei prepared in this fasion. In normal rats, $25-35 \%$ of the total pituitary tracer $\mathrm{T} 3$ was recovered in the nuclear pellet. Nonspecific nuclear binding was $2.4 \pm 0.1 \%(\mathrm{SE})$ of total pituitary $\mathrm{T}_{3}$ in rats receiving 20 $\mu \mathrm{g} \mathrm{T}_{3}$. After the saline washes, $1 \mathrm{ml}$ of absolute ethanol was added to the nuclear pellet which was vortexed and incubated at $37^{\circ} \mathrm{C}$ water bath. A mean of $80 \pm 0.09 \%$ of specifically bound nuclear $T_{3}$ was recovered from the isolated nuclei. RIA results were corrected for this loss which was documented for each pituitary. The DNA content of the extracted pellet was measured by the method of Burton (10) as modified by Giles and Myers (11). Recovery of pituitary DNA was $85-90 \%$.

RIA of $T_{3}$ in the nuclear extract. The $T_{3}$ in the dried extract was dissolved in $0.1 \mathrm{ml}$ of $0.1 \mathrm{~N} \mathrm{NaOH}$. Then $0.44 \mathrm{ml}$ of glycine-acetate buffer (GAB, $0.2 \mathrm{M}$ glycine, $0.13 \mathrm{M}$ sodium acetate, $\mathrm{pH} 8.6$ ) was added followed by $0.1 \mathrm{ml}$ of a $32 \%$ $\mathrm{vol} / \mathrm{vol} \mathrm{T}_{3}$-free human serum solution in GAB. Recovery of $\left.{ }^{125} \mathrm{I}\right] \mathrm{T}_{3}$ from the dried extract was $100 \%$. The following solu- tions were also prepared: sodium salicylate, $27.4 \mathrm{mg} / \mathrm{ml}$ in CAB containing $0.01 \%$ bovine serum albumin (GAB-BSA); rabbit anti- $\mathrm{T}_{3}$ antibody diluted $1: 3.6 \times 10^{-5}$ in GAB-BSA as described (12); tracer $T_{3}, 1,500-2,500 \mathrm{cpm}(2-4 \mathrm{pg}) / 50 \mu \mathrm{l}$ of GAB-BSA. Each $200 \mu \mathrm{l}$ of diluted standard contained 10 $\mu \mathrm{l}$ of $\mathrm{T}_{3}$-free human serum in GAB in addition to $\mathrm{T}_{3}(0.3-20$ pg). The assay was prepared as follows: $200 \mu \mathrm{l}$ of standard or unknown were added to glass tubes followed by $100 \mu \mathrm{l}$ of sodium salicylate solution and $150 \mu \mathrm{l}$ of antibody solution. Nonspecific binding was assessed for each pituitary nuclear sample and for the assay as a whole by substitution of GAB-BSA for the antibody solution. After $2 \mathrm{~d}$ incubation at $4^{\circ} \mathrm{C}, 50 \mu \mathrm{l}$ of $\left[{ }^{125} \mathrm{I}\right] \mathrm{T}_{3}$ solution was added and after a further $2 \mathrm{~d}, 1 \mathrm{ml}$ of dextran-charcoal solution in GAB. The tubes were then incubated for $40 \mathrm{~min}$ in an ice-water bath after which they were centrifuged at 2,000 $\mathrm{g}$ for $15 \mathrm{~min}$ and the supernate decanted and counted. The charcoal solution was a 1:64 dilution in GAB of a suspension containing $1.2 \mathrm{~g}$ dextran and $12.5 \mathrm{~g}$ decolorizing norit charcoal per liter GAB. Sufficient counts were collected to achieve $>95 \%$ counting accuracy. The $\left[{ }^{125} \mathrm{I}_{3} \mathrm{~T}_{3}\right.$ present in the nuclei did not contribute significantly to the counts added for the RIA.

In Fig. 1 is shown a typical displacement curve for $T_{3}$. Specifically bound $\mathrm{T}_{3}$ ranged from 22 to $30 \%$. The minimum detectable $T_{3}$ concentration as defined by that dose resulting in $\left.{ }^{125} \mathrm{I}\right] \mathrm{T}_{3}$ displacement from antibody greater than two standard deviations from the "zero" binding varied from 0.6 to $2.5 \mathrm{pg} \mathrm{T}_{3} / \mathrm{tube}$. In most assays, it was $1.25 \mathrm{pg}$. The quantity of $\mathrm{T}_{3}$ that caused a $50 \%$ decrease from zero binding was between 5 and 8 pg/tube.

Determination of serum $\left[{ }^{125} I\right] T_{3}$ concentrations. We have previously reported that trichloroacetic acid precipitation of serum from tracer $T_{3}$-injected rats results in artifactually high values for $T_{3}$ recovery. This is caused by the presence

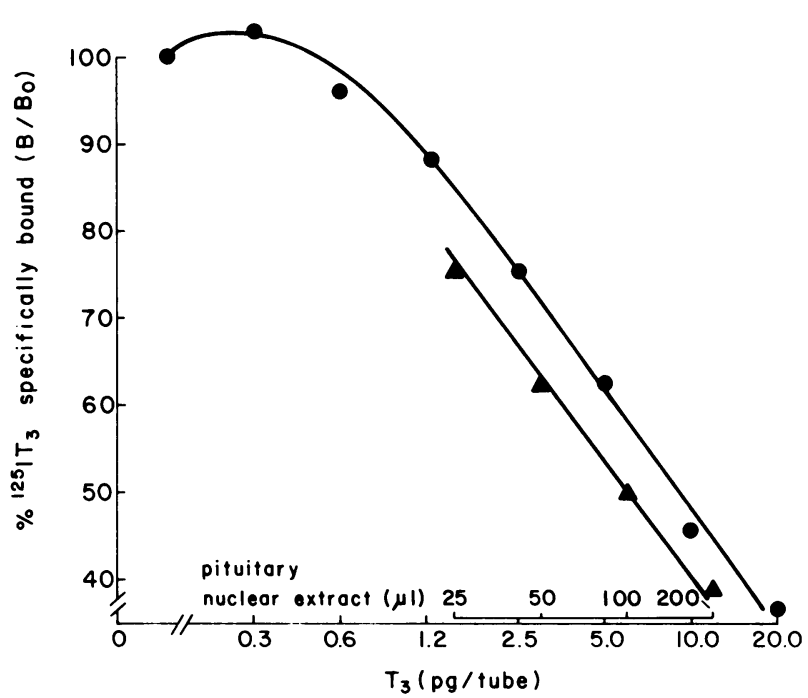

Figure 1 Displacement of antibody bound $\left.{ }^{125} \mathrm{I}\right] \mathrm{T}_{3}$ by increasing quantities of unlabeled $\mathrm{T}_{3}$. This displacement curve is compared with that obtained by increasing quantities of resuspended anterior pituitary nuclear extract from euthyroid, male Sprague-Dawley rats. In this experiment, the total binding of $\left.{ }^{125} \mathrm{I}\right] \mathrm{T}_{3}$ alone was $31.7 \%$ and nonspecific binding was $10 \%$. Nonspecific binding in the pituitary nuclear extracts was $11.7 \%$. A volume of $100 \mu \mathrm{l}$ is approximately equivalent to the quantity of nuclear extract used in the standard RIA of pituitary nuclean $T_{3}$. $B_{0}$, zero binding. 
of non- $\mathrm{T}_{3}$, protein-bound, labeled compounds that are generated or concentrated relative to $T_{3}$ after intravenous injection $(3,6)$. Therefore, $\left[{ }^{125} \mathrm{I}\right] \mathrm{T}_{3}$ from sera of injected rats was isolated using specific $T_{3}$ antibody coupled to agarose as we have described $(6,13)$. Recovery of authentic (uninjected) $\left[{ }^{131} \mathrm{I}\right] \mathrm{T}_{3}$ from $0.1 \mathrm{ml}$ rat serum in this system varied from 40 to $60 \%$. The quantities of tracer $\left[{ }^{125} \mathrm{I}\right] \mathrm{T}_{3}$ were corrected for this simultaneously determined recovery and the results were expressed as a fraction of the trichloroacetic acid-precipitable injected $\left[{ }^{125} \mathrm{I}\right] \mathrm{T}_{3}$ dose. Trichloroacetic acid precipitation is a valid technique for assessing the fraction of uninjected tracer that is not $\mathrm{I}^{-}$.

Miscellaneous methods. $\left[{ }^{125} \mathrm{I}\right] \mathrm{T}_{3}$ and $\left[{ }^{131} \mathrm{I}\right] \mathrm{T}_{3}$ were synthesized in the laboratory according to the method of Weeke and Orskov (14). The specific activity was 3,200-3,400 $\mu \mathrm{Ci} / \mu \mathrm{g}$. Serum $\mathrm{T}_{3}$ and $\mathrm{T}_{4}$ were assayed by methods described $(2,15)$. Serum TSH in rats was measured using materials kindly provided by the National Pituitary Agency using reported modifications of the methods that are provided with these materials (16). $T_{3}$ and $T_{4}$ were the free acid and were obtained from Sigma Chemical Co., St. Louis, Mo. All results are mean $\pm S E$. Statistical comparison of means was performed by either paired or unpaired $t$ tests as appropriate.

\section{RESULTS}

RIA methodology. Shown in Fig. 1 is the displacement of $\left.{ }^{125} \mathrm{I}\right] \mathrm{T}_{3}$ from antibody by increasing aliquots of pituitary nuclear extract. For this experiment, the nuclear extract from six anterior pituitaries of euthyroid rats were pooled and redissolved in onehalf the customary buffer volume. In Fig. 1, $100 \mu \mathrm{l}$ corresponds roughly to the quantity of nuclear extract customarily present per tube. As shown, the displacement caused by increasing quantities of nuclear extract is parallel to the displacement curve for authentic $\mathrm{T}_{3}$. Nonspecifically bound $\mathrm{T}_{3}$ in the standard tubes varied from 7 to $11 \%$. As previously discussed, a variable portion (one-third to one-half) of this "nonspecifically" bound label is ${ }^{125} \mathrm{I}^{-}$which does not bind to charcoal (12). The remainder is a result of residual protein- $\mathrm{T}_{3}$ binding. The $640-\mu \mathrm{l} \mathrm{vol}$ in which the nuclear extract was redissolved allowed two samples of 200 $\mu \mathrm{l}$ for $\mathrm{T}_{3}$ assay and a single $200 \mu \mathrm{l}$ for evaluation of nonspecific bonding. In each assay, 6-12 nuclear extracts were measured and the mean of the nonspecific binding values was determined for both the standard curve and the pituitary nuclear extracts. The nonspecific $\mathrm{T}_{3}$ binding in the nuclear extracts was consistently $0.5-1.5 \%$ higher than in the standard curve samples but varied $<1.5 \%$ between individual samples. The observed percent bound for each unknown was corrected for this difference.

The quantity of $T_{3}$ per tube in the assay depended upon the thyroid status of the rat and on the recovery of nuclear $T_{3}$ throughout the isolation procedure. The major losses occurred in the isolation of the nuclei $(10-15 \%)$ and in the ethanol extraction of $T_{3}$ from nuclei $(20 \%)$. Therefore, because the total pituitary nuclear extract was divided into 3.2 aliquots, roughly
$21 \%$ of the pituitary nuclear $\mathrm{T}_{3}$ was assayed in each tube. For normal rats and hypothyroid rats injected with $\mathrm{T}_{3}$ (see below), this resulted in roughly 5-6 pg of $T_{3}$ per tube. In hypothyroid rats not given $T_{3}$, $<1-2$ pg of $\mathrm{T}_{3}$ were present per tube.

Anterior pituitary nuclear $T_{3}$ in chronically hypothyroid rats with and without injected $T_{3}$. In Table I, part A, are shown anterior pituitary nuclear $T_{3}$ measurements in seven hypothyroid rats. The serum $T_{3}$ in these rats was $16 \pm 3.6 \mathrm{ng} / \mathrm{dl}$ and serum $\mathrm{T}_{4}$ was $<0.25$ $\mu \mathrm{g} / \mathrm{dl}$ confirming the hypothyroid state. This was further verified by measurements of TSH that were $>1,000 \mu \mathrm{U} / \mathrm{ml}$ with a normal range for our assay of $50-250 \mu \mathrm{U} / \mathrm{ml}$. Rats prepared in this fashion also have extremely low hepatic mitochondrial $\alpha$-glycerophosphate dehydrogenase activities in addition to cessation of weight gain and are then physiologically hypothyroid in spite of clearly detectable serum $T_{3}$ concentrations $(17,18)$. The nuclear $\mathrm{T}_{3}$ by RIA in these rats was $9.1 \mathrm{pg} /$ pituitary or $0.18 \mathrm{pg} / \mu \mathrm{g}$ DNA. In the last two columns of Table $I$ are shown the expected $T_{3}$ values based on the nuclear:serum ratio for $\left[{ }^{125} \mathrm{I}\right] \mathrm{T}_{3}$ in each animal and the serum $\mathrm{T}_{3}$ measured in a sample obtained just before the tracer injection. The expected nuclear $\mathrm{T}_{3}$ was $2.9 \mathrm{pg}$ or $0.05 \mathrm{pg} / \mu \mathrm{g}$ DNA which was significantly less than was measured $(P<0.05)$. The mean discrepancy was $6 \mathrm{pg}$ of nuclear $\mathrm{T}_{3} /$ pituitary.

In part B of Table $\mathrm{I}$ are shown nuclear $\mathrm{T}_{3}$ measurements in chronically hypothyroid animals given $400 \mathrm{ng}$ of $\mathrm{T}_{3} / 100 \mathrm{~g}$ body wt containing ${ }^{125} \mathrm{I} / \mathrm{T}_{3}$. This dose was chosen because our previous studies suggested it would nearly saturate the anterior pituitary nuclear receptors for $T_{3}(2)$. The gravimetric concentration of the injected $\mathrm{T}_{3}$ was further verified by assay of suitable dilutions of the dose in the same assay with the nuclear extracts. Because the specific activity of the administered $T_{3}$ was known, the accuracy of the method could be assessed by comparison of the measured nuclear $T_{3}$ with that expected from the specific activity. The calculation included the small contribution to injected $T_{3}$ of the endogenous $T_{3}$ present in the serum before $T_{3}$ injection $\left(<10 \%\right.$ of the injected $\left.\mathrm{T}_{3}\right)$. The expected quantity of $\mathrm{T}_{3}$ was calculated from the counts present in each ethanol extract. A mean of $1.87 \times 10^{-4}$ of the $T_{3}$ dose was present per pituitary $60 \mathrm{~min}$ after injection and $15 \%$ of this $\mathrm{T}_{3}$ was found in the nuclear extract. The mean nuclear $T_{3}$ measured was $34 \pm 2.5(\mathrm{SE})$ pg or $1 \mathrm{pg} \mathrm{T}_{3} / \mu \mathrm{g}$ DNA. This was not significantly different from the value of 0.96 per pg $T_{3} \mu \mathrm{g}$ DNA for the maximal binding capacity of anterior pituitary nuclei of hypothyroid rats determined by saturation analysis (2). The expected nuclear $T_{3}$ based on specific activity calculations was $20 \pm 1.5 \mathrm{pg} \mathrm{T}_{3}$ or $0.85 \pm 0.03 \mathrm{pg} \mathrm{T}_{3}$ per $\mu \mathrm{g}$ DNA. The 5-pg discrepancy between the measured and the expected nuclear $T_{3}$ was significant $(P<0.025)$.

Nuclear and total anterior pituitary $T_{3}$ in normal 
TABLE I

Anterior Pituitary Nuclear $T_{3}$ Measured by RIA

\begin{tabular}{|c|c|c|c|c|c|c|c|c|}
\hline \multirow[b]{2}{*}{ Animal wt } & \multirow[b]{2}{*}{ Pit wet wt } & \multirow[b]{2}{*}{ Pit DNA } & \multirow[b]{2}{*}{ Serum $\mathrm{T}_{3}$} & \multirow[b]{2}{*}{ Serum $T_{4}$} & \multicolumn{4}{|c|}{ Nuclear $\mathrm{T}_{3}$} \\
\hline & & & & & \multicolumn{2}{|r|}{ Measured } & \multicolumn{2}{|c|}{$\begin{array}{l}\text { Expected from serum } \\
\mathrm{T}_{3} \text { and the } \\
\text { nuclear:serum ratio }\end{array}$} \\
\hline$g$ & $m g$ & $\mu g$ & $n g / d l$ & $\mu g / d l$ & $p g$ & $p g / \mu g D N A$ & $p g$ & $p g / \mu g D N A$ \\
\hline \multicolumn{9}{|c|}{ A Chronically hypothyroid rats $(n=7)$} \\
\hline $\begin{array}{r}238 \\
\pm 8\end{array}$ & $\begin{array}{r}10.1 \\
\pm 0.6\end{array}$ & $\begin{array}{l}50 \\
\pm 3.1\end{array}$ & $\begin{array}{c}16 \\
\pm 3.6\end{array}$ & $<0.25$ & $\begin{array}{r}9.1 \\
\pm 2.9\end{array}$ & $\begin{aligned} & 0.18(<0.05)^{*} \\
\pm & 0.06\end{aligned}$ & $\begin{array}{r}2.9 \\
\pm 0.8\end{array}$ & $\begin{array}{r}0.05 \\
\pm 0.01\end{array}$ \\
\hline
\end{tabular}

B Chronically hypothyroid rats given $400 \mathrm{ng} \mathrm{T}_{3} / 100 \mathrm{~g}$ body wt $60 \mathrm{~min}$ previously $(n=10)$

\begin{tabular}{|c|c|c|c|c|c|c|c|c|}
\hline \multirow[b]{2}{*}{256} & \multirow{3}{*}{$\begin{array}{r}9.2 \\
+0.44\end{array}$} & \multirow{3}{*}{$\begin{array}{l}35 \\
+1.9\end{array}$} & \multirow[b]{2}{*}{ - } & \multirow[b]{2}{*}{$<0.25$} & \multicolumn{2}{|r|}{ Measured } & \multicolumn{2}{|c|}{$\begin{array}{c}\text { Expected from serun } \\
\mathrm{T}_{3} \text { and the } \\
\mathrm{T}_{3} \text {-specific activity } t\end{array}$} \\
\hline & & & & & 34 & $1.00(<0.025)^{*}$ & 29 & 0.85 \\
\hline \pm 12 & & & & & \pm 2.5 & \pm 0.6 & \pm 1.5 & \pm 0.03 \\
\hline
\end{tabular}

C Euthyroid male Sprague-Dawley rats $(n=29)$

\begin{tabular}{ccccccrrr} 
& & & & Measured & \multicolumn{2}{c}{$\begin{array}{c}\text { T } \\
\text { nuclear:serum ratio } \$\end{array}$} \\
372 & 8.8 & 44 & 55 & 4.0 & 28 & $0.63(<0.001)^{*}$ & 9.8 & 0.23 \\
\pm 11 & \pm 0.25 & \pm 1.7 & \pm 2.0 & \pm 0.21 & \pm 1.9 & \pm 0.04 & \pm 0.7 & \pm 0.02 \\
\hline
\end{tabular}

* Figures in parentheses are $P$ values for the statistical significance (by paired $t$ test) of the difference between the measured value and that expected.

$\neq$ The pituitaries of these rats contained $1.87 \pm 0.13(\mathrm{SE}) \times 10^{-2} \%$ of the $\mathrm{T}_{3}$ dose per anterior pituitary. Tracer $\mathrm{T}_{3}$ in the assayed nuclear extract was $15 \pm 1(\mathrm{SE}) \%$ of the total anterior pituitary $\mathrm{T}_{3}$.

$\S$ Assayed nuclear $\mathrm{T}_{3}$ was $30 \pm 1 \%(\mathrm{SE})$ of the total anterior pituitary tracer $\mathrm{T}_{3}$.

rats. In part $\mathrm{C}$ of Table $\mathrm{I}$ are shown analyses of anterior pituitary nuclear $\mathrm{T}_{3}$ in 29 euthyroid animals. Serum $\mathrm{T}_{3}$ concentrations in these rats were $55 \pm 2(\mathrm{SE})$ $\mathrm{ng} / \mathrm{dl}$ and serum $\mathrm{T}_{4}$ concentrations $4.0 \pm 0.21 \mu \mathrm{g} / \mathrm{dl}$. The pituitary glands of these animals were smaller relative to body weight than were those of the hypothyroid rats, but the quantity of DNA/ $\mu$ g wet wt of pituitary was not significantly different. Nuclear $\mathrm{T}_{3} 28 \pm 1.9 \mathrm{pg}$ corresponding to $0.63 \mathrm{pg}$ of $\mathrm{T}_{3} / \mu \mathrm{g}$ DNA. The mean nuclear $\mathrm{T}_{3}$ calculated from the product of the $60-\mathrm{min}$ nuclear: serum ratio $(0.42 \pm 0.02)$ and the radioimmunoassayable serum $\mathrm{T}_{3}$ was only $9.8 \mathrm{pg}$ of nuclear $\mathrm{T}_{3}$ or $0.23 \mathrm{pg} / \mu \mathrm{g}$ DNA. The difference between these two values was substantial (18 pg/pituitary) and highly significant ( $P$ $<0.001)$. In previous studies, the nuclear $\mathrm{T}_{3}$ receptor binding capacity in the anterior pituitary of the euthyroid rat by saturation analysis was estimated to be 0.77 (12) to 0.79 (19) $\mathrm{pg} / \mu \mathrm{g}$ DNA. The value of $0.63 \mathrm{pg} \mathrm{T}_{3} /$ $\mu \mathrm{g}$ DNA represents $82 \%$ saturation of these nuclear $\mathrm{T}_{3}$ receptors. Because we also determined that the $\mathrm{T}_{3}$ isolated in these nuclei represented $30 \pm 1 \%$ of the total anterior pituitary $T_{3}$ in these animals, it was possible to calculate total pituitary $T_{3}$ which was $92 \pm 6 \mathrm{pg}$, an average of $10.5 \mathrm{pg} \mathrm{T}_{3}$ /wet wt.

Since the quantities of nuclear $\mathrm{T}_{3}$ measured in the hypothyroid animals given $\mathrm{T}_{3}$ and in the normal animals were quite similar, and because the nuclear: serum ratio for tracer $T_{3}$ in the hypothyroid animals was also known, we compared the calculated nuclear: serum $T_{3}$ ratios for tracer $T_{3}$ with those of radioimmunoassayable $T_{3}$ in both experiments. The serum $\mathrm{T}_{3}$ concentrations in the hypothyroid rats were the sum of the injected $\mathrm{T}_{3}$ determined from the serum counts and the specific activity and the preinjection radioimmunoassayable $T_{3}$. These data are summarized in Table II. In the 10 hypothyroid rats given $400 \mathrm{ng}$ $\mathrm{T}_{3} / 100 \mathrm{~g}$ body $\mathrm{wt}$, the nuclear:serum ratio for tracer $\mathrm{T}_{3}$ was $0.14 \pm 0.1$, whereas that for radioimmunoassayable $\mathrm{T}_{3}$ was $0.18 \pm 0.1$. These values were not significantly different. In the 29 normal rats, the nuclear:serum ratio for tracer $\mathrm{T}_{3}$ was $0.42 \pm 0.02$, whereas that for radioimmunoassayable $T_{3}$ was $1.2 \pm 0.08$. The difference between these two ratios was highly significant ( $P$ $<0.001)$. The fraction of nuclear $T_{3}$ derived from 
TABLE II

Comparison of Nuclear:Serum Ratios for Tracer $T_{3}$ and $T_{3}$ by RIA (Mean \pm SE)

\begin{tabular}{|c|c|c|}
\hline Nuclear $\mathrm{T}_{3} /$ Serum $\mathrm{T}_{3}$ & Hypothyroid rats & Normal rats \\
\hline \multicolumn{3}{|c|}{$400 \mathrm{ng} T_{3} / 100 \mathrm{~g}$ body $u t$} \\
\hline$n$ & 10 & 29 \\
\hline cpm $\mathrm{T}_{3} / \mu \mathrm{g} \mathrm{DNA} / \mathrm{cpm}_{3} / \mu \mathrm{l}$ serum & $0.14 \pm 0.01$ & $0.42 \pm 0.02$ \\
\hline $\mathrm{pg} \mathrm{T}_{3} / \mu \mathrm{g} \mathrm{DNA} / \mathrm{pg} \mathrm{T}_{3} / \mu \mathrm{l}$ serum & $0.18 \pm 0.02(\mathrm{NS})^{*}$ & $1.19 \pm 0: 08(P<0.001)^{*}$ \\
\hline
\end{tabular}

* Statistical comparisons performed by paired $t$ test.

plasma $\mathrm{T}_{3}$ in normal rats can be obtained by dividing the nuclear:serum ratio for tracer $T_{3}$ by that for radioimmunoassayable $T_{3}$. The quotient is 0.35 indicating that, as assessed by this technique, $35 \%$ of pituitary nuclear $\mathrm{T}_{3}$ derives from plasma $\mathrm{T}_{3}$, whereas $65 \%$ derives from intrapituitary $T_{4}$ to $T_{3}$ conversion.

\section{DISCUSSION}

Methodology. The data in Fig. 1 and in Table I, indicate that the recovery of $T_{3}$ from pituitary nuclei is adequate and that the material extracted from the nuclei gives a parallel displacement curve to that obtained with authentic $\mathrm{T}_{3}$. However, it appears from Table I, part $\mathrm{B}$, that the recovery of known quantities of $\mathrm{T}_{3}$ from the nuclei is $\sim 17 \%$ (or $5 \mathrm{pg}$ ) above that expected based on specific activity calculations. A similar discrepancy of $6 \mathrm{pg}$ was observed in pituitary nuclei from hypothyroid rats though this might be attributed in part to the small quantities of $T_{3}$ being assaved. Control studies have shown that there is no $\mathrm{T}_{3}$-like material either in the ethanol or in the solutions used to isolate nuclei or reconstitute the dried nuclear extracts. There remain several possible explanations for the discrepancy. One is that some pituitary nuclear $\mathrm{T}_{3}$ could be attributed to the presence of quantities of $\mathrm{T}_{4}$ in the serum that are below the limit of detectability using the $\mathrm{T}_{4}$ assay described $(0.25 \mu \mathrm{g} / \mathrm{dl})$. A rough estimate of this potential contribution can be made as follows. We have previously reported that in euthyroid rats, the nuclear $T_{3}$ derived from serum $T_{4}$ via intrapituitary conversion is $1.3 \pm 0.2 \times 10^{-2} \times \mathrm{ng} \mathrm{T} / \mathrm{ml}$ serum per mg DNA (6). In a euthyroid rat with a plasma $T_{4}$ of $40 \mathrm{ng} / \mathrm{ml}$, this source would contribute $0.52 \mathrm{ng} \mathrm{T}_{3} / \mathrm{mg}$ DNA (or pg $T_{3} / \mu \mathrm{g}$ DNA). $T_{4} 5^{\prime}$-monodeiodination is approximately threefold more active in vitro in anterior pituitary fragments from hypothyroid rats than in those from euthyroid animals (4). This difference is supported by comparison of the ratios of pituitary nuclear $\left[{ }^{125} \mathrm{I}^{1} \mathrm{~T}_{3}\right.$ to serum $\left[{ }^{125} \mathrm{I}\right] \mathrm{T}_{4}$ determined in vivo which are also higher in hypothyroid rats $(2,6)$. Therefore, a serum $\mathrm{T}_{4}$ of $2 \mathrm{ng} / \mathrm{ml}$ in a hypothyroid rat could result in $1.3 \times 10^{-2}$ $\times 3 \times 2 \mathrm{ng}$ or $0.08 \mathrm{pg} \mathrm{T}_{3} / \mu \mathrm{g}$ DNA in anterior pituitary nuclei. Because $50 \mu \mathrm{g}$ of DNA are recovered in the pituitary nuclear pellet, this source might account for as much as $4 \mathrm{pg} \mathrm{T}_{3}$ /pituitary.

A second consideration is in the accuracy of the determination of the nuclear per serum $\mathrm{T}_{3}$ ratio and consequently the expected nuclear $\mathrm{T}_{3}$. It has been previously determined that the only point at which the specific activity of $T_{3}$ in the serum is the same as that of the portion of the intracellular $\mathrm{T}_{3}$ pool derived from serum is at the time of peak nuclear occupancy (the "equilibrium time point" or $\left.t_{m}\right)(20-22)$. We have shown that there does not appear to be a demonstrable $t_{m}$ for pituitary nuclear $\mathrm{T}_{3}$ but rather a period of maximum nuclear $T_{3}$ that may last from 30 to 120 min after $T_{3}$ injection $(1,6)$. During this time, the tracer $T_{3}$ in the serum is decreasing. Because the nuclear $T_{3}$ remains constant as serum $T_{3}$ falls, the nuclear:serum ratio is rising over the $t_{m}$. The difference in the nuclear:serum ration between $30 \mathrm{~min}$ and $2 \mathrm{~h}$ can be as much as $50 \%$ (6). Because we presume there is an actual $t_{m}$ but recognize that this moment is impossible to detect given the limits of the experimental methods, we have chosen a time of $60 \mathrm{~min}$ for these studies which both we and Oppenheimer et al. (19) have estimated to be the best approximation of the midpoint of the $t_{m}$ for the euthyroid pituitary (6). An underestimate of the nuclear: serum ratio could explain a relatively small portion of the above discrepancy because the increment of $50 \%$ in expected nuclear $T_{3}$ would apply only to that quantity of nuclear $T_{3}$ derived from the endogenous $T_{3}$ present in the serum. Lastly, it is possible that there are crossreacting $T_{3}$-like substances in the nuclear extract. This possibility cannot be rigorously excluded on the basis of the present information.

Despite the above, the present method would appear to have satisfactory accuracy for the purposes of the present study, especially in light of the 18-pg $T_{3} /$ pituitary discrepancy between observed and expected nuclear $\mathrm{T}_{3}$ in anterior pituitary nuclei from euthyroid rats. This large difference can be attributed to the $T_{3}$ derived from intrapituitary $\mathrm{T}_{4}-5^{\prime}$-monodeiodination and therefore confirms our earlier tracer studies (6). The discrepancy of $0.40 \mathrm{pg} \mathrm{T}_{3} / \mu \mathrm{g}$ DNA is quite similar to the predicted contribution of serum $\mathrm{T}_{4}$ to anterior pituitary nuclear $\mathrm{T}_{3}\left(0.52 \mathrm{pg} \mathrm{T}_{3} / \mu \mathrm{g} \mathrm{DNA}\right)$ as calculated 
above for rats with a serum $T_{3}$ of $40 \mathrm{ng} / \mathrm{ml}$ based on our previous report (6). The estimation of the quantity of nuclear $T_{3}$ derived from intrapituitary $T_{4}-5^{\prime}$-monodeiodination depends on both the RIA of total nuclear $\mathrm{T}_{3}$ and the estimate of the contribution of serum $\mathrm{T}_{3}$ to nuclear $T_{3}$ via the nuclear:serum $T_{3}$ ratio. The limitations of the latter with respect to the pituitary have been discussed above. Even if the appropriate nuclear: serum $\mathrm{T}_{3}$ ratio were as much as $50 \%$ higher, the measured nuclear $\mathrm{T}_{3}$ of $28 \mathrm{pg}$ would still be substantially more than the $14 \mathrm{pg}$ which could then be attributed to serum $T_{3}$. However, the estimate of the fraction of the nuclear $T_{3}$ derived from $T_{4}$ in this case would decrease from 65 to $50 \%$. Another way of evaluating these results is presented in Table II. The similarity of the tracer and RIA nuclear:serum $T_{3}$ ratios in the $T_{3}$-injected hypothyroid rats is in marked contrast to the discrepancy between these two nuclear:serum $\mathrm{T}_{3}$ ratios in the normal rats where serum $T_{4}$ is present.

Comparison of these results with previous studies. We are not aware of previous RIA measurements of pituitary nuclear $T_{3}$, but two reports of total pituitary $\mathrm{T}_{3}$ measurements have been published. Gordon and Spira (23) measured anterior pituitary $\mathrm{T}_{3}$ in a pool of 100 rat pituitaries and obtained a result of $6.8 \mathrm{pg} / \mathrm{mg}$ wet wt, a value which is approximately two-thirds of that which we have observed. In a more recent report, Obregon et al. (24) measured total pituitary $\mathrm{T}_{3}$ in female Wistar rats with unspecified body and pituitary weights (24). They found a total pituitary $\mathrm{T}_{3}$ of $70 \pm 4$ (SE) pg per anterior pituitary gland. Because it is likely that these female rats were smaller than the males used in this study, the value calculated for total pituitary $T_{3}$ would appear to be in good agreement with that of these authors, though somewhat higher than that of Gordon and Spira.

Physiological implications. We have previously shown that in both hypothyroid and euthyroid rats, the apparent contribution of intracellular $T_{4}$ to $T_{3}$ conversion to nuclear $T_{3}$ was much greater in the pituitary gland than it was in the liver, kidney, or heart $(2,6)$. The results suggested that this source of nuclear $T_{3}$ might be quantitatively significant in pituitary and less so in other tissues. The substantial excess of radioimmunoassayable pituitary nuclear $T_{3}$ over that predicted from serum $\mathrm{T}_{3}$ measurements is in marked contrast to the general agreement between these two methods for estimating $\mathrm{T}_{3}$ in liver and kidney nuclei reported by Surks and Oppenheimer (25).

An important consequence of the intrapituitary $T_{3}$ derived from $T_{4}$ is that it results in a greater saturation of the nuclear $T_{3}$ receptors in this tissue than can be obtained from serum $\mathrm{T}_{3}$ alone at its endogenous concentration. The 0.63-pg $\mathrm{T}_{3} / \mu \mathrm{g}$ DNA in the present studies would result in $82 \%$ saturation of anterior pituitary nuclear receptors which is quite similar to our previous estimate of $78 \%$ saturation based on pulseinjection tracer methodology (6). The latter studies also suggested that $<10 \%$ of pituitary nuclear iodothyronine is $\mathrm{T}_{4}$. If the anterior pituitary nuclear iodothyronine receptor does bear a casual, inverse relationship to $\mathrm{TSH}$ production as has been suggested from our data $(1,2)$ and from studies of pituitary thyrotrophs in culture (26), and if the nuclear receptor saturation in thyrotrophs is similar to the average pituitary value of $82 \%$, then TSH secretion could increase and remain increased when serum $T_{4}$ is reduced even if serum $T_{3}$ remains or returns to normal. This would have an important role in the compensatory response of the thyrotroph to early hypothyroidism or iodine deficiency. It differs importantly from the situation in most other tissues of the rat that would appear to depend largely if not entirely on serum $\mathrm{T}_{3}$ alone for nuclear $\mathrm{T}_{3}$. A high degree of endogenous nuclear $\mathrm{T}_{3}$ receptor saturation in the somatotrophs of euthyroid rats might also explain the failure of growth hormone secretion to increase after thyroid hormone administration as reported by Couloumbe et al. (27). The physiological explanation for the unique importance of local $\mathrm{T}_{4}-5^{\prime}$-monodeiodination as a source of intracellular $\mathrm{T}_{3}$ in this critically important endocrine tissue is not understood at the present time.

\section{ACKNOWLEDGMENTS}

We gratefully acknowledge the careful secretarial assistance of Ms. Lorraine Sevigny.

This work was supported in part by grants AM21797 and AM18616 from the National Institutes of Health.

\section{REFERENCES}

1. Silva, J. E., and P. R. Larsen. 1977. Pituitary nuclear 2,5,3'triiodothyronine and thyrotropin secretion: an explanation for the effect of thyroxine. Science (Wash. D. C.). 198: $617-620$.

2. Silva, J. E., and P. R. Larsen. 1978. Contributions of plasma triiodothyronine to nuclear triiodothyronine receptor saturation in pituitary, liver and kidney of nine receptor saturation in pituitary, liver and kidney of hypothyroid rats. Further evidence relating saturation of pituitary nuclear triiodiothyronine receptors and the acute inhibition of thyroid-stimulating hormone release.J. Clin. Invest. 61: 1247-1259.

3. Larsen, P. R., T. E. Dick, B. P. Markovitz, M. M. Kaplan, and T. G. Gard. 1979. Inhibition of intrapituitary thyroxine to $3,5,3^{\prime}$-triiodothyronine conversion prevents the acute suppression of thyrotropin release by thyroxine in hypothyroid rats. J. Clin. Invest. 64: 117-128.

4. Cheron, R. G., M. M. Kaplan, and P. R. Larsen. 1979. Physiological and pharmacological influences on thyroxine to 3,5,3'-triiodothyronine conversion and nuclear $3,5,3^{\prime}$ triiodothyronine binding in rat anterior pituitary. J. Clin. Invest. 64: 1402-1414.

5. Kaplan, M. M. 1978. T4 to T3 conversion in rat pituitary homogenate. Program of the 54th Meeting of the American Thyroid Association. T-6. (Abstr.)

6. Silva, J. E., T. E. Dick, and P. R. Larsen. 1978. The contribution of local tissue thyroxine monodeiodination 
to the nuclear 3,5,3'-triiodothyronine in pituitary, liver and kidney of euthyroid rats. Endocrinology. 103: 1196-1207.

7. Silva, J. E., M. M. Kaplan, R. G. Cheron, T. E. Dick, and P. R. Larsen. 1978. Thyroxine to 3,5,3'-triiodohtyronine conversion by rat anterior pituitary and liver. Metab. Clin. Exp. 27: 1601-1607.

8. Bavli, S. Z., J. E. Silva, P. R. Larsen, and M. Castonguay. 1978. Radioimmunoassay of rat anterior pituitary (AP) nuclear triiodothyronine $\left(\mathrm{NT}_{3}\right)$. Program of the 54 th Meeting of the American Thyroid Association. T-18. (Abstr.)

9. Samuels, H. H., and J. S. Tsai. 1973. Thyroid hormone action in cell culture: demonstration of nuclear receptors in intact cells and isolated nuclei. Proc. Natl. Acad. Sci. U. S. A. 70: 3488-3492.

10. Burton, K. 1956. A study of the conditions and mechanism of the diphenylamine reaction for the colorimetric estimation of deoxyribonucleic acid. Biochem. J. 62: 315-323.

11. Giles, K. W., and A. Myers. 1965. An improved diphenylamine method for the estimation of deoxyribonucleic acid. Nature (Lond.). 205: 93.

12. Larsen, P. R. 1972. Direct immunoassay of triodothyronine in human serum. J. Clin. Invest. 51: 1939-1949.

13. Zimmerman, D. J., M. Izumi, and P. R. Larsen. 1978. Isolation of labeled triiodothyronine from serum using affinity chromatography: application to the estimation of the peripheral T4 to T3 conversion in rats. Metab. Clin. Exp. 27: 303-313.

14. Weeke, J., and H. Orskov. 1973. Synthesis of monolabeled $3,5,3^{\prime}$-triiodothyronine and thyroxine of maximum specific activity for radioimmunoassay. Scand.J. Clin. Lab. Invest. 32: 357-360.

15. Larsen, P. R., J. Dockalova, D. Sipula, and F. M. Wu. 1973. Immunoassay of thyroxine in unextracted human serum. J. Clin. Endocrinol. Metab. 37: 177-182.

16. Silva, J. E., and P. R. Larsen. 1978. Peripheral metabolism of homologous thyrotropin in euthyroid and hypothyroid rats: acute effects of thyrotropin-releasing hormone, triiodothyronine and thyroxine. Endocrinology. 102: 17831796.

17. Frumess, R. D., and P. R. Larsen. 1975. Correlation of serum triiodothyronine $\left(\mathrm{T}_{3}\right)$ and thyroxine $\left(\mathrm{T}_{4}\right)$ with biological effects of thyroid hormone replacement in propylthiouracil-treated rats. Metab. Clin. Exp. 24: 547-554.

18. Larsen, P. R., and R. D. Frumess. 1977. Comparison of the biological effects of thyroxine and triiodothyronine in the rat. Endocrinology. 100: 980-988.

19. Oppenheimer, H. H., H. L. Schwartz, and M. I. Surks. 1974. Tissue differences in the concentration of triiodothyronine nuclear binding sites in the rat: liver, kidney, pituitary, heart, brain, spleen and testis. Endocrinology. 95: 897-903.

20. Matthews, C. M. E. 1957. The theory of tracer experiments with ${ }^{131}$ I-labeled plasma proteins. Phys. Med. Biol. 2: 36-53.

21. Pearson, J. D., N. Veall, and H. Vetter. 1958. A practical method for plasma albumin turnover studies. Strahlentherapie. 38: 290-297.

22. Oppenheimer, J. H., H. L. Schwartz, D. Koerner, and M. I. Surks. 1974. Limited binding capacity sites for 1-triiodothyronine in rat liver nuclei: nuclear-cytoplasmic interrelation, binding constants, and cross-reactivity with 1-thyroxine. J. Clin. Invest. 53: 768-888.

23. Gordon, A., and O. Spira. 1975. Triiodothyronine binding in rat anterior pituitary, posterior pituitary, median eminence and brain. Endocrinology. 96: 1357-1365.

24. Obregon, M. M., A. Pascual, G. Morreale de Escobar, and F. Escobar del Ray. 1979. Pituitary and plasma thyrotropin, thyroxine, and triiodothyronine after hyperthyroidism. Endocrinology. 104: 1467-1473.

25. Surks, M. I., and J. H. Oppenheimer. 1977. Concentration of L-thyroxine and L-triiodothyronine specifically bound to nuclear receptors in rat liver and kidney: quantitative evidence favoring a major role of $T_{3}$ in thyroid hormone action. J. Clin. Invest. 60: 555-562.

26. Gershengorn, M. C. Regulation of thyrotropin production by mouse pituitary thyrotropic tumor cells in vitro by physiological levels of thyroid hormones. Endocrinology. 102: $1122-1128$.

27. Coulombe, P., H. L. Schwartz, and J. H. Oppenheimer. 1978. Relationship between the accumulation of pituitary growth hormone and nuclear occupancy by triiodothyronine in the rat. J. Clin. Invest. 62: 1020-1028. 